\title{
$\int$ Prologue: A Century OF PHOTO-POETIC ENCOUNTERS
}

In February 2010 I attended a poetry reading in Moscow by the contemporary Russian writer Sergei Gandlevsky. In the discussion afterward, moderated by the late writer and translator Asar Eppel', an audience member asked Gandlevsky to speak about his creative process: how he comes up with ideas for poems and how he goes about writing them. I was struck by how Gandlevsky characterized both the moment of poetic inspiration and his broader writing practice in terms of photographic processes. In his telling, the inspiration for a poem transpires with the suddenness of a photo-camera's flashbulb, transforming an initial image or combination of words into something that fixes in his mind and endures in his fragile memory. ${ }^{1}$

I go for walks with my dog or ride on the electric train. And I just stumble upon a word combination ... Oh! And I remember it. And a year or two later something might stick to it. ... I mean, clearly something must happen in my brain. I don't exactly have a brilliant memory, you know? . . But I remember clearly everything that was around me in that moment of "Oh!": where it was, the weather . . apparently there's a kind of surge that happens in your brain. It's like everything gets recorded by a magnesium flashbulb. ${ }^{2}$

Later in his remarks, while describing the process by which he subsequently fills out the text of a poem around this initial snapshot of an idea, Gandlevsky likened the composition process to a metaphorical photograph coming into view, as if in a darkroom developing solution. Describing the emergence of a poem stanza by stanza he said, "I might walk for a long time and moan and groan ... And then something just ... aha! And another stanza appears, and then another. And then, basically, it's done. That's it. I'm the author and this is my poem. It's as if the poem emerges from the photographic fixing solution, you know?"3 For Gandlevsky, inspiration comes as a sudden photo-flash 
illumination of an idea that is fixed in a form that will not be forgotten. Conversely, the struggle to flesh out the poem's ideas and language is closer to the photographic developing process, wherein the body of the text gradually reveals itself until it is a fully formed, stable entity. It is perhaps not by accident that Gandlevsky elsewhere in this postreading discussion uses the word oblik (appearance)-with its roots in lik (face, countenance) and its connection to portraiture or icon painting - to refer to the idea of the wholly completed poetic text. This oblik of a fully realized poem is like the photographic snapshot, fixed such that it will not fundamentally be altered ("it's basically all there, you can't scare it off at this point" [ono uzhe vse, ego uzhe ne spugnesh']). ${ }^{4}$

Gandlevsky, elsewhere in his works, characterizes his genesis as a poet in terms of still and moving images. A poem titled "First Snow, as if Filmed in Slow Motion" (Pervyi sneg, kak v zamedlennoi s"emke) from his 2006 cycle Portrait of an Artist as a Young Man (Portret khudozhnika v otrochestrve) details the earliest moments of his self-conceptualization as a writer. ${ }^{5}$ The poem's author-speaker describes the way he, as a young person, first began to see the world in poetic terms, concluding with the lines "He said to himself: Hey, why not / Be a writer? That's what he became" (On skazal sebe: 'Chto kak tebe / Stat' pisatelem?' Vot on i stal im). The poem uses photographic, optical, and cinematic imagery to illuminate these formative moments of his call to poetry. ${ }^{6}$

Первый снег, как в замедленной съёмке,

На Сокольники падал, пока,

Сквозь очки озирая потёмки,

Возвращался юннат из кружка.

...

Двор сиял, как промытое фото.

Веренице халуп и больниц

Сообщилось серьёзное что-то-

Белый верх, так сказать, чёрный низ.

The first snow, as if filmed in slow motion

At Sokolniki fell to the ground

Through his glasses the darkness reflected

A young naturalist returning from Scouts.

The yard shone like a just-printed photo.

A serious something conveyed

To the row of small huts and the hospitals-

White on top, so to speak, black below. ${ }^{7}$ 
For Gandlevsky, the language of photography and its aesthetic and temporal qualities become a metaphor to explain both his origins as a poet and his writerly practice.

In 1913, nearly a century before Gandlevsky's remarks, an experimental writer Tikhon Churilin (1885-1946) composed a two-part poem he titled "In Photozincography" (V fototsinkografii), which also frames his selfconception as a poet in terms of photo-chemical metaphors. ${ }^{8}$ Churilin suffered from schizophrenia (mania presledovaniia) and underwent psychiatric treatments throughout his adult life. ${ }^{9}$ His first book of poems, Spring after Death (Vesna posle smerti), was published in 1915 and included several lithograph illustrations by Natalia Goncharova. The book represents a new awakening and renewed sense of possibility after the dark days of mental illness, hunger strikes, and forced feedings he underwent in a psychiatric hospital during late 1909-12, a period of his life he referred to as his "two years of spiritual death." ${ }^{10}$ Nikolai Gumilev characterized the book as built around a "strict logic of madness and truly delirious imagery" and described Churilin's primary focus as the experience of a person "closely approaching madness, sometimes even fully mad." 11 The poet was lauded as "brilliant" by his close friend and fellow poet Marina Tsvetaeva. ${ }^{12}$

In part 1 of the poem "In Photozincography," subtitled "Photo from a Portrait" ( $S$ "emka s portreta), the poet uses photozincography-the process of transferring a photographic negative onto a light-sensitive zinc plate for reproduction or enlargement-as an allegory of the poet-speaker's selfconception as a figure of power.

\section{Съемка с портрета}

Светлый свет

Ярко брызнул на бледный

Мой портрет.

Вот теперь я, поэт,

-Победный! ${ }^{13}$

\section{A radiant light}

Flashed brightly on my

Pale portrait.

Now there I am, a poet,

-Victorious!

The lyric speaker, subsequently witnessing the triumphant transfer of his image, sees himself momentarily as a tsar ("I am like a tsar at a feast") (Ia kak 
tsar' na piru). But when a blaze of sun-glazed color and a menacing knock at the window invade his psyche, his image undergoes a sudden metaphorical transfer to the next stage of chemical fixing, and the triumphant tsarpretender is snuffed out ("Click-the coffer slams shut. / The tsar is snuffed.") (Khlop—zakhlopnuli lar' / —Potukh tsar'). ${ }^{14}$

The second part of the diptych, "The Developing Process" (Proiavlenie), figures the lyric speaker-in conversation with his double—confronting his own image as it emerges from a developing solution of poison within the closed-off, deathly space of the darkroom of his damaged mind.

\section{Проявление}

Маленькая мертвая каморка

Темная, как ад.

Смотрим оба зорко:

В кюветке—яд, туда наш взгляд.

Вот ...

На черном радостном фоне-белый урод.

Это я ... .

-Жалит змея меня.

Это ты.

-Кряхтят в норе кроты.

Как странно . . . как странно ново.

-Слово:

Ну, всё,-гготово.

Ах一угорели? Во тьме-нездорово. ${ }^{15}$

The small, deathly closet room is

Dark, like hell.

We both look fixedly:

Our gaze directed at the poison in the developing tray

There...

On the gleeful black background-a white freak.

That's me...

"The snake is biting me."

That's you.

"The moles are grunting in their burrow."

How strange ... how strangely new.

"The word":

Well, that's it. Ready.

Oh! All poisoned by the fumes? It's unhealthy in the dark. 
The uncanny use of photo-chemical processes as a metaphor for selfactualization and mental deterioration in Churilin and the representation of poetic inspiration in photographic terms by Gandlevsky are just two examples illustrating the range of creative possibilities that emerge from poetic encounters with the photographic. This book explores how twentieth-century Russian poets, who were actively writing between Churilin and Gandlevsky, have come to relate aspects of the poetic process to the aesthetics and mechanics of photographic processes. Photography operates as both inspiration and opponent for modernist poets for whom language is the main material for expression within a world increasingly saturated with images. Much more than simply a study of ekphrasis - of poems that describe photographs-this book takes as its central question something broader, opening scholarship to the investigation of deeper ontological connections between the lyric and the snapshot.

This book asks what compels a poet to turn to a photograph, whether as the subject of a work, as material for metaphor, or as the structural framework for a poem. Snapshots of the Soul represents part of a growing body of scholarship that investigates the way that photography operates as the material or method for poetic writing in the twentieth century. Drawing on theories of lyric and elegy, the social history of technology, and littleknown materials from the Russian literary archives, this book considers how encounters with photographs and photography enter the space of poetic writing for a range of Russian-language poets, in émigré contexts as well as in Soviet and post-Soviet Russia. Through analysis of photography's role in the creative worlds of Boris Pasternak (1890-1960), Marina Tsvetaeva (1892-1941), Joseph Brodsky (1940-96), and Bella Akhmadulina (1937-2010), and in a selection of works by other modern and contemporary poets, this book asks how and why poets are drawn to the language, representational power, and metaphorical possibilities that photography offers. We will see how photography's status as a visual threat to the verbal arts compels these writers to harness the poetic word to confront, engage, and sometimes transcend the compelling force of photographic verisimilitude. 

$\boldsymbol{S}$ SNAPSHOTS OF THE SOUL 
